\title{
Inventory of Research Relevant to Higher Education in Canada
}

\section{Inventaire des recherches sur l'Enseignement supérieur au Canada}

\author{
J. F. HOUWING, A. M. KRISTJANSON, L. F. MICHAUD
}

\section{Introduction}

This issue of Stoa completes the 1973-74 inventory of research studies relevant to higher education in Canada. Some 170 research projects reported to the AUCC Research Division in the survey administered in the fall of 1973 were classified under six subject sections. The projects classified under section " $A$ ", General; "B", Administration; and "C", Curriculum and Teaching, appeared in Stoa volume IV, no. $1,1974$.

The summary of research studies pertaining to sections $\mathrm{D}, \mathrm{E}$, and $\mathrm{F}$ are given below. Those wishing complete crossreferences of listed projects and author's contributions must refer to the previous issue of Stoa in conjunction with this one.

All projects completed or in progress after the first of January 1973 and identified through the 1973 survey have thus been released. It is planned to prepare a 1974-1975 inventory by conducting a survey in the fall of 1974 .

\section{Introduction}

Avec cette livraison de Stoa nous terminons l'impression de l'inventaire des recherches ayant trait à l'enseignement supérieur au Canada pour l'année 19731974. Quelques 170 projets de recherche ont été signalés à la Division de la recherche de l'AUCC lors d'une enquête menée à l'automne 1973. Ces projets ont été groupés sous six catégories. Les projets cla classés sous les sections " $A$ ", " $B$ " et " $C$ " ont été donnés dans la livraison précédente de Stoa volume IV, no. 1, 1974.

La description des projets de recherche ayant trait aux sections $D, E$, et $F$ parait ci-dessous. Ceux qui désirent vérifier la liste de tous les projets et les noms d'auteurs devront consulter la livraison précédente de Stoa en même temps que celle-ci.

Tous les projets terminés ou en voie d'exécution après le ler janvier 1973 et dont on a fait rapport dans l'enquête 1973 ont maintenant été rendus publiques. Une nouvelle enquête pour identifier les projets de l'année 1974-1975 sera menée à l'automne de 1974. 


\section{Academic and Non-Academic Staff / Personel enseignant et non enseignant}

D1 a) Mémoire soumis à la Commission d'étude sur la classification des enseignants b) Principes qui devraient présider à la mise en place d'un système de classification des enseignants de l'élémentaire, du secondaire et du collégial c) Déc. 1973 d) Conférence des recteurs et des principaux des universités du Québec, 6600 Chemin de la Côte des Neiges, suite 300, Montréal 249, Qué.

D2 a) Tenure b) Summary of current studies; classification of issues; problems encountered with tenure systems; suggestions for the future c) May 74 d) Conférence des recteurs et des principaux des universités du Québec, 6600 Chemin de la Côte des Neiges, suite 300, Montréal 249, Qué.

D3 a) Nurse educators' receptivity to educational change: an empirical study b) PhD dissertation c) June 1973 d) Junette J. Douglin e) OISE library

D4 a) Characteristics of post-secondary teachers b) Characteristics such as citizenship, salary, country of first degree and country of last degree are a few of the variables that have been studied. New ones will be added to expand the realm of study as well as continue the analysis of trends in higher education c) Continuing d) Harvey Ford, Wilfred Dubé and Louise Desramaux, Statistics Canada, Ottawa, Ont.

D5 a) Status of women employees at the University of Alberta b) Statistical enquiry into the existing career and salary structure of academic women employees at the university. Information obtained from the personnel office records is analysed by using the model and techniques of multiple regression analysis. The objective is to assess the contributions of the sex variable to an academic staff member's salary level c) April 1974 d) Nirmal Mehra, Office of Institutional Research and Planning, University of Alberta

Cross reference / Renvois: see also / voir aussi: A11, A13, A28, B4, B28, C37, C38, C39, E33 and F7

\section{E Students / Etudiants}

E1 a) The impact of job opportunities upon students' decisions to seek post-graduate education: a case study of chemistry students in Ontario b) Addressed to both a current educational planning problem (unemployment of persons with graduate degrees and its implications for graduate enrollment policy) and to an area of inquiry and empirical research (career decisions and occupational choice), the research will draw from, and contribute to, the theory of career decisions. An intensive case study approach has been chosen as the most fruitful one and graduate chemistry students have been selected c) June 1973 d) W. Alexander and M. Skolnik, OISE

E2 a) The critical juncture (educational and vocational intentions of grade 12 students in Ontario) b) To assess educational/vocational plans and social, cultural and economic characteristics of grade 12 students for fall 1973 and 1974 ; follow-up of students to assess fit between stated intentions and actual plans c) June 1974 d) Paul Anisef, McLaughlin College, York University

E3 a) Students'perceptions of authority as a determinant of their involvement within the university c) 1974 d) A.N.A. Azim, Faculty of Business, University of Calgary

E4 a) High school students' perception and evaluation of their post-high-school alternatives b) Designed to explain aspects of the recent trend affecting post-high-school choices - high school graduates have increasingly over the past years perceived and acted upon a number of apparently viable alternatives to the traditional university-directed post-secondary model. The study investigates what alternatives to this traditional model are perceived and what factors motivate students to opt for a university education or for one of the alternatives c) June 1974 d) R. Baker, OISE

E5 a) Validity of academic predictors in prediction of university success b) Designed to develop a system by which teacher marks from school to school can be compared for predicting average overall grades at the end of the first university year and specific grades in specific courses. The study, involving a large Ontario university and its feeder schools, will compare schools on various predictors of university success such as high school marks and objective tests; assess various predictors; and select a best set of academic predictors c) June 1974 d) R. P. Bhargava, S. B. Khan and V. R. D'Oyley, OISE E6 a) An enquiry into educational experience of part time university students b) The project will report on the development, current status and projections of 1 st cycle part-time university studies 
in the English and French sectors in Montreal, and identify social and psychological factors which encourage or discourage mature students from continuing with this form of study c) June 1974 d) J. Bhatnagar, 12425 Richer Blvd., Pierrefonds, Qué.

E7 a) Educational and occupational plans of high school students b) A questionnaire was completed by over 1000 high school students in the Calgary area to provide information on occupational aspirations, expectations and their correlates. Multivariate analysis currently being completed c) Ongoing d) Merlin B. Brinkerhoff, Dept. of Sociology, University of Calgary

E8 a) The distribution of student marks for the years $1970-71$ and 1971.72 b) Analysis of students' marks assigned under the nine-point grading system at the University of Alberta to determine if the distribution of marks conformed to an established theoretical distribution and if it was consistent across the university and over time c) May 1973 d) Kenneth W. Coull, Office of Institutional Research and Planning, University of Alberta

E9 a) The impact of community colleges in British Columbia b) Study of students entering the colleges to determine socio-economic, attitudinal and academic characteristics; performance of transfer students to universities; and college faculty and community views on colleges c) May 1974 d) John D. Dennison, Fac. of Educ., University of British Columbia, Alex Tunner, B. C. Research, and Gordon Jones, Vancouver City College, Vancouver, B. C.

E10 a) A study of York non-returnees during $1972-73$ b) Questionnaire study of reasons for dropping out, experiences at York, present activities, future plans and suggestions c) Jan. 1974 d) Morris N. Eagle, Dept. of Psychology, York University

E11 a) University drop-outs b) Investigation of student withdrawals from universities. Some of the mediating variables studied have been regional differences, variation according to university size and sex differences d) Y. Ferland, Statistics Canada, Ottawa, Ont.

E12 a) Financial information on Canadian universities b) To study the amount of federal and provincial aid to university students. In addition, tuition, living accommodations and costs at each university as well as income and expenditure of Canadian universities are being analyzed d) R. Frank and S. La Buissonnière, Statistics Canada, Ottawa, Ont.

E13 a) Anglophone and francophone New Brunswick students - the development of civic attitudes b) Survey of students in four communities to determine at what time and by what processes they acquired their political attitudes and a knowledge of the functions of their political institutions c) Aug. 1973 d) Thomas P. Gleason, Department of Educ. Foundations, Memorial University, and Jean-Guy Finn, 531 Highcroft, Ottawa, Ont.

E14 a) Study of repayment habits and problems of borrowers repaying Canada student loans b) Study to determine the questionnaire to be forwarded to all students who have previously had Canada student loans and are now in the process of repayment. It will request information from students as to their knowledge of the repayment procedures, their actions with respect to repayment, the actions taken by the bank, and, if applicable, the collection agency c) Spring 1974 d) Guaranteed Loans Administration, Department of Finance, Ottawa, Ont.

E15 a) Compilation of statistics on actual Canada student loans applications b) Statistics available will be income brackets of parents of applicants, number of dependents, ages of applicants, amount of aid granted - provincial loan, federal loan and provincial grant etc. This will hopefully be an annual study c) June 1974 d) Guaranteed Loans Administration, Department of Finance, Ottawa, Ont. E16 a) Secondary analysis of policy issues in post-secondary education b) Concerned with the issue of equalizing educational opportunity through access to post-secondary institutions, it is hypothesized that the variables of sex, ethnicity, and socio-economic status (as measured by father's education) all exercise an effect upon the individual's educational chances, independent of his or his family's financial resources. Consequently, an effort should be made by decision-making bodies to ensure that inequalities arising from these factors be considered in the formulation of access policy. Me thodology employed involves the secondary analy sis of data collected by Statistics Canada for their post-secondary student population survey, 1968-1969 c) June 1973 d) E. B. Harvey, OISE E17 a) Aide à l'étudiant et égalité des chances b) Analyse du fichier du Service de l'aide aux étudiants du ministère de l'Education du Québec afin de découvrir les relations entre le sort réservé au dossier d'aide et les caractéristiques des candidats d) Valérien Harvey, Université Laval E18 a) Policy, academic, and social determinants of success in post-secondary education b) To 
examine the interrelationships among: policy behavior of university and college officials concerning selecting, counselling, rewarding, evalua ting, and expelling of students; academic behavior (accomplishments) of Ontario secondary students; socio-economic status of secondary school students; and the stock of qualified manpower in the province. The output will be a set of admissions-retention policy alternatives, accompanied by expected effects upon students' behavior and the stock of highly qualified manpower in Ontario c) June 1973 d) J. Holland and S. Quazi, OISE

E19 a) Survey of York undergraduates $1972-73$ b) Concerned with predicting return of students eligible to return to university, the study consists of three reports: future plans of undergraduates; York as a place to study; and follow-up to find out whether those planning to return in fact did so c) 1973 d) Clifford Jansen, Sociology Dept., York University

E20 a) Survey of York undergraduates $1973-74$ b) Repetition of the 1972-73 survey (see previous entry), using prediction models based on the first study and large samples within faculties c) July 1974 d) Clifford Jansen, Sociology Dept., York University

E21 a) Performance of college transfer students in the business administration faculty, University of Alberta b) Statistical comparison of transfer students from Alberta colleges with students admitted directly from high school. Academic performance measured in terms of grade point average and faculty recommendation c) Dec. 1973 d) C. Janssen, Fac. of Business Administration and Sharon Batt, Office of Institutional Research and Planning, University of Alberta

E22 a) The partial non-persister community college student b) Investigation into certain characteristics and opinions of a limited sample of college students who have withdrawn from some (but not all) of their courses in which originally enrolled. Size of class, time of day class was given, opinions of counsellors and instructors, reasons for original enrollment, reported reasons for withdrawal, and opinions of students as to what could or might have been done to lessen the chance of withdrawal are reported c) March 1973 d) Gordon Jones, Vancouver City College, Vancouver 15, B. C. and John D. Dennison, University of British Columbia

E23 a) Traineeship for nurses in remote medically underserviced areas to study post-basic family practice nursing b) A project to overcome financial and geographic barriers of nurses living in remote and medically underserviced areas who wish to become qualified nurse practitioners by completing a university course in family practice nursing c) March 1975 d) Dorothy J. Kergin, School of Nursing, McMaster University

E24 a) Manitoba student aid program data base b) To provide: basic demographic characteristics of program participants; socio-economic characteristics of the families of applicants considered dependent on parental financial support; basic description data on non-sequential (not entering directly from Grade 12) and step-out (take one or more years off) students; and range of research plans, e.g. the effect of aid on accessibility, regional variations in levels of support, demographic changes in the education population. Information is confidential and, when available, in anonymous format c) Jan. 1974 d) F. R. Kleiman, Special Support Branch, Department of Colleges and Universities Affairs, Winnipeg, Man.

E25 a) Influence de certaines qualités de la relation éducative et du comportement du mattre sur l'efficacité de l'enseignement b) Etude des facteurs reliés au changement de l'étudiant sous un double aspect: celui de la perception que l'étudiant a des qualités de relations interpersonnelles de ses professeurs et celui des stratégies d'enseignement. Le changement de l'étudiant est mesuré par l'actualisation de sa personnalité et son rendement scolaire c) 1974 d) Aimée Leduc et Gérard Scallon, Fac. des Sciences de l'éducation, Université Laval

E26 a) Cheating at Scarborough College b) Study of cheating behaviours and attitudes (15 page mimeo) c) 1973 d) John A. Lee, Sociology Dept., Scarborough College, University of Toronto E27 a) Sixty professors on cheating b) Study of cheating behaviours and attitudes (15 page mimeo) c) 1973 d) John A. Lee, Sociology Dept., Scarborough College, University of Toronto

E28 a) Why they came to Scarborough College b) Study of student enrolment motivations (15 page mimeo) c) 1973 d) John A. Lee, Sociology Dept., Scarborough College, University of Toronto E29 a) Why they did not return to Scarborough College b) Study of student enrolment motivations (15 page mimeo) c) 1973 d) John A. Lee, Sociology Dept., Scarborough College, University of Toronto

E30 a) Preliminary report on undergraduate student flow patterns b) Attempt to map the patterns 


\section{Inventory of Research}

of student flow through the University of Alberta undergraduate programs. Contains summarized rates of attrition, admission, and retention for the first two years of study in some of the larger, non-professional faculties for the years 1967-68 to $1972-73$ c) Oct. 1973 d) J. M. Litwin and Kenneth W. Coull, Office of Institutional Research and Planning, University of Alberta

E31 a) A report on women taking part-time degree courses at the University of Waterloo b) Survey set out to make some preliminary judgments about the role the university currently plays in the parttime education of women c) June 1973 d) Isobel Mackay, University of Waterloo

E32 a) Study of athletic programs in Canadian universities and colleges b) To study the universities' role in developing contemporary sport and the purpose of this role in the educational programs; the scope of the present athle tic programs and the interrelationship between these programs and the educational programs; the interrelationship between the universities' athletic programs and the amateur sports governing bodies, the coaching associations, the regional athletic associations and CIAU c) June 1974 d) A. W. Matthews, AUCC Research Division, 151 Slater St., Ottawa, Ont.

E33 a) Patterns of learning projects among physical education professionals b) To measure the extent and to determine some of the characteristics of learning by teachers of physical education. Subjects will be a random sample of physical education teachers in Toronto. Data will be collected by means of a highly structured interview. Extent of learning will be measured in terms of learning projects. The study will also be concerned with the content and planning of learning and credit as a motivation for learning c) Aug. 1974 d) Cressy A. M. McCatty, School of Physical and Health Educ., University of Toronto

E34 a) Socio-psychological correlates of non-medical use of drugs among university students b) Three chief objectives: to provide a general description of student involvement in drug usage; to isolate factors significantly associated with drug-use; and to detect those which contribute maximally to it. Data was obtained from a sample of 282 respondents (17\% of the resident population in Lister Hall complex) c) 1973 d) Nirmal Mehra, Office of Institutional Research and Planning, University of Alberta

E25 a) Who goes when to college? b) The paper compares two groups of students, those who seek university registration in mid-year and those who register in the beginning of the academic year. The main conclusion is that the spring semester students, although relatively lower on high school grade point average, tend to perform comparably in freshman courses c) 1973 d) Nirmal Mehra, Office of Institutional Research and Planning, University of Alberta

E36 a) Pass-fail grading systems: a literature review b) Comment on the evaluation schema of student academic performance. "Standards", "evaluation" and "grades" are defined. A brief history of grading among early North American institutions of higher learning was compared to precursory practices in Europe. The validity and reliability of traditional grades were examined. Finally, the original review of the literature on pass-fail was presented c) 1973 d) David Otto, Office of Institutional Research and Planning, University of Alberta

E37 a) Early academic and social adjustment of graduate students from A sian countries at the University of Saskatchewan, Saskatoon Campus b) Study of adjustment problems encountered by 21 Asian graduate students. The study found that the students had little preparation before leaving their own countries and most experienced discrepancies between expectations and experiences concerning Canadian people and the academic demands of their programs. Difficulties were due largely to English language deficiencies and unfamiliar methods of instruction c) May 1973 d) Yongyudh Plianpadung, Chiengmai University, Muang District, Chiengmai, Thailand e) University of Saskatchewan

E38 a) The effects of behavioral objectives on student achievement b) The project has, so far, demonstrated that in an area in which attainment can be measured precisely and students may be expected to have some previous knowledge the use of behavioral objectives produces a decrement in learning for all conditions of instruction. Further research to find if there are types of subject matter and student characteristics for which behavioral objectives will facilitate learning c) June 1974 d) Arthur M. Sullivan and Clarence Patten, Junior Division, Memorial University E39 a) Part-time: the student and the method b) Designed to challenge the educational assumptions thought to underlie the present distinctions, primarily the one that part-time experience is second rate with respect to fulltime experience. The overall hypothesis that such distinctions are both ineffec- 
tive and destructive to the post-secondary enterprise will be tested by means of collecting and analyzing existing North American data and new data on part-time students and part-time study c) June 1974 d) A. Thomas and D. Ironside, OISE

E40 a) Characteristics of post-secondary school students b) A data bank of informatin on characteristics (age, sex, region, etc.) of post-secondary school students will be analyzed c) 1974 d) Guy Tremblay, David Robertson and Magella Quinn, Statistics Canada, Ottawa, Ont.

E41 a) The relationship between attendance at Selkirk College and performance at the University of British Columbia of high school graduates of School Districts 7-12 b) The records at the university of high school graduates from Districts $7-12$ (served by Selkirk College) will be examined as to performance, graduation, drop out rate, etc. and significant differences sought between those who attended the college prior to entering the university and those who entered directly c) Spring 1974 d) Brian Webster, Selkirk College, Castlegar, B.C.

E42 a) Education of Canadian women and girls project b) To identify and reproduce significant historical documents concerning the education of women and girls in Canada. Such documents will be grouped in logical form and published for use in universities and colleges, where courses on women are proliferating c) June 1974 d) T. J. Wigney, OISE

E43 a) Commuting student study II b) Re-examination of the degree of responsiveness of campus informal space facilities to the unique needs of University of Alberta commuting students. Assessment of student study, lounge, recreational, food, service, and commercial space use, satisfaction and needs. As many improvements have been made since the first study, the restudy will determine if space provision is now adequate. More emphasis on student campus environmental concerns and student time patterns will be included in the restudy c) July 1974 d) $\mathrm{Wm}$. J. Williamson, Office of Institutional Research and Planning, University of Alberta

E44 a) The University of Alberta mature student housing study b) Although a sample of all mature students will be studied, the requirements of single mature students are of particular interest. The housing needs of the latter appear to require further consideration in the overall student housing provision e) April 1974 d) Wm. J. Williamson, Office of Institutional Research and Planning, University of Alberta

Cross-reference / Renvois: see also/voir aussi: A13, A28, C23, C27, C28, F8 and F9

\section{F Extension and Continuing Education / Education permanente}

F1 a) Development of a continuing health administration program b) To develop a continuing education program of self-contained short courses dealing with specific content areas for which there are identifiable needs in the Canadian health care system and geared to an advanced level for experienced administrative personnel in health care c) Aug. 1973 d) John H. Babson, School of Health Administration, University of Ottawa

F2 a) The development of a training program in continuing education b) Particularly for Alberta: to assess the need for men and women with training in continuing education in terms of numbers and capabilities required; to determine what resources and expertise are now available; to ascertain the character of significant programs in Canada, the U.S.A., and the U.K.; and to sketch a framework, content, and modus operandi of a training program in continuing education c) Oct. 1974 d) Duncan D. Campbell, Dept. of Extension, University of Alberta

F3 a) Continuing education in the Canadian university b) Study of the development of university continuing education function in terms of: current institutional and public attitudes toward it; character of the programs offered and the organization, financing, and staffing of the function; future role of the university in light of contemporary developments in Canada and elsewhere c) Oct. 1975 d) Duncan D. Campbell, Dept. of Extension, University of Alberta

F4 a) Community viewpoint: a community development education project b) A university extension project evaluating four methods of providing education in community development in four regions of the province c) Jan. 1974 d) Glen M. Farrell, Extension Division, University of Saskatchewan, Saskatoon Campus

F5 a) P. A. Woodward mobile instructional resource centre (MIRC) - continuing education in the 
health sciences b) MIRC consists of a highway bus equipped with three teaching carrels, containing $35 \mathrm{~mm}$ slide projectors, super- 8 cassette loaded film projectors, audio tape decks and video playback facilities. It will travel to about 50 small isolated communities in B. C. and remain in each for about a week during which time all health professionals in the community will have an opportunity to use it c) March 1976 d) E. J. Hyde, Div. of Cont. Educ. in the Health Sciences, University of British Columbia

F6 a) Concepts and strategies: comparative studies in adult education b) To determine the feasibility of undertaking a comparative study of the Ontario CAATs and the Quebec CEGEPs. Specifically, to determine sources and accessibility of data, probable cooperation from each system, common problem areas and sectors in which information exchange could be most useful. Secondary purpose is to identify alternative modes of comparison suitable for the proposed study with particular attention to systems analysis c) June 1973 d) R. Kidd, OISE

F7 a) Comprehensive curriculum project: comparative studies in adult education b) Part of an on-going program to develop comparative studies in adult education not only at OISE but in universities in several parts of the world. Major activities in the coming year are: preparation, testing, and utilization of "guidelines" for professors of adult education; preparation of videotaped and oral-taped interviews with leading theorists in comparative education; the bringing together of these components with the "Books of Readings" already produced in the project; and preparation for a major book in this field c) June 1974 d) J. R. Kidd, OISE

F8 a) Patterns of learning projects among professional men b) To investigate the extent and some of the characteristics of adult learning. Participation was measured in terms of learning projects. Subjects of the study were a sample of 54 professional men. Findings support the view that adults engage extensively in learning. Vocational learning accounted for $55 \%$ of the learning projects. Self-planned learning was most common. Credit was a minor source of learning motivation. Ph.D. dissertation c) May 1973 d) Cressy A. M. McCatty, School of Physical and Health Education, University of Toronto e) OISE and University of Toronto libraries

F9 a) The planning behaviour and conceptual complexity of clergymen in self-directed learning projects relating to their continuing professional education b) To develop a taxonomy of planning events and a typology of planning behaviours used by 60 clergymen involved in self-directed learning projects related to their continuing professional education. Planning behaviours are also examined according to conceptual development of the individuals c) Sept. 1974 d) John F. Morris, Extension Dept., University of New Brunswick

$\mathrm{F} 10$ a) A proposed in-service training program for academic administrators in Ontario community colleges b) To develop a proposal by means of a modified Delphi technique for a continuing inservice training program for (potential) administrators in the academic divisions c) Spring 1974 d) George H. Robertson, Sir Sandford Fleming College, Peterborough, Ont.

F1 1 a) DETA b) Designed for engineers and architects, the DETA training program is aimed chiefly at creating a manpower reserve and optimizing the effectiveness of experienced personnel. It is divided in to the training and development of recent graduates and the technical recycling of experienced engineers and architects c) Feb. 1973 d) D. Schwartz, Sciences and Technology Program, Public Service Commission, Ottawa, Ont.

F12 a) The use of VTR equipment in community development b) Exploratory project to investigate the use of videotape recording equipment as a tool in community development. Two years' field experience was used to develop a communication theory relative to the use of VTR in the community c) Dec. 1973 d) Roy M. K. Wagner, Extension Division, University of Saskatchewan, Saskatoon Campus

Cross-reference / Renvois: see also/voir aussi: C3, C16 and E33

\section{Index of Research Workers / Index des chercheurs}

$\begin{array}{llll}\text { Alexander, W. } & \text { E1 } & \text { Babson, J. H. } & \text { F1 } \\ \text { Anisef, P. } & \text { E2 } & \text { Baby, A. } & \text { C2 } \\ \text { Ayers, J. D. } & \text { C1 } & \text { Bain, H. W. } & \text { C3 } \\ \text { Azim, A. N. A. } & \text { E3 } & \text { Baker, R. } & \text { E4 }\end{array}$


94 J. F. Houwing, A. M. Kristjanson, L. F. Michaud

\section{Batt, S.}

Beaudoin, G.

Bhargava, R. P.

Bhatnagar, J.

Brehaut, W.

Brinkerhoff, M. B.

Butt, R. L.

Cahoon, M. C.

Cameron, J. R.

Campbell, D. D.

Campbell, G.

Cardillo, B.

Cerny, E.

Clements, K.

Coleman, A. J.

Collins, J. B.

Cornish, D.

Coull, K. W.

Crouse, W. F.

Crowley, R. W.

Daniel, J. S.

Dennison, J. D.

Desramaux, L.

Din, S. ud

Donald, J. G.

Douglin, J. J.

D'Oyley, V. R.

Dubé, W.

Eagle, M. N.

Edwards, G. D. J.

Eppell, F. J.

Farrell, G. M.

Ferland, Y.

Finn, J. -G.

Fiorino, A.

Ford, $\mathrm{H}$.

Fortier, J. O.

Foster, S. F.

Frank, R.

Gagnon, N.

Gailitis, M.

Geis, G. L.

Giroux, R.

Glass, H. P.

Gleason, T. P.

Gold, A. J.

Guérin, G.

Hardwick, W. G.

Harvey, E. B.

Harvey, V.

Holland, J.

Holland, M.

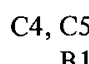

C4, C5

B 1

E5

E6

A 30

E7

$\mathrm{C} 42$

C3

$\mathrm{A} 1, \mathrm{~A} 2$

F2, F3

A3

B35

C20

B2

C7

A4

A7

E8, E30

A8

C10

C11

E9, E22

D4

C43

A25

D3

E5

D4

E10

C7

$\mathrm{C} 12$

F4

E11

E13

A9

D4

C11

C13

E12

C44

B5

A10

A.23

B6

E13

C14

B7, B8

A4

A11, B9, B10, B11, E16

E17

A12, B12, E18

A13
Horowitz, P.

Hyde, E. J.

Ingram, E. J.

Ironside, $\mathrm{D}$.

Jacobs, D. E.

Jansen, C.

Janssen, C.

Johnston, C. M.

Jones, $\mathrm{G}$.

Kelly, G.

Kelsey, G.

Kergin, D. J.

Khan, S. B.

Kidd, J. R.

Kleiman, F. R.

Knapper, C. K.

Konrad, A. G.

Kuch, P. J.

C28

F5

A14, A15

E39

A11

E19, E20

E21

A16

E9, E22

A31

A14

C16, E23

E5

F6, F7

E24

C13, C17

A14, B13

B14

La Buissonnière, $\mathrm{S}$.

E12

Laferrière, $\mathrm{T}$.

Lakaski, C.

Leclerc, M.

Leduc, A.

Lee, J. A.

Lévesque-Michaud, M.

Litwin, J. M.

C2

B35

$\mathrm{C} 18, \mathrm{C} 30, \mathrm{C} 32$

E25

E26, E27, E28, E29

Macdonald, R. St. J.

C2

E30

Mackay, I.

C19

Maddigan, R.

E31

Malik, M. F.

Matthews, A. W.

McCatty, C. A. M.

McIntosh, R. G.

McIntyre, J. W. R.

C41

$\mathrm{C} 20$

E32

E33, F8

A15

C21

McLean, L. D.

B5

McLeish, J.

$\mathrm{C} 22$

Mehra, N.

Migué, J. -L.

More, R. H.

Morris, J. F.

Mulrooney, D.

Munroe, D. C.

B15, B 16, D5, E34, E35

B 17

B18

$\mathrm{C} 23, \mathrm{~F} 9$

C24

A17

Nadeau, G. G.

$\mathrm{C} 13$

O’Bryan, M.

$\mathrm{C} 25$

Olivier, W.

$\mathrm{C} 26$

Otto, D.

C27, C28, E36

Parent, J.

Patten, C.

C29, C30, C32

E38

C31

Pelletier, D.

A19

Pepper, E. F

C32 
Plianpadung, $\mathrm{Y}$.

Powell, $\mathrm{T}$.

Preshing, Wm. A.

Prock, L. M.

Proulx, P. -P.

Quazi, S.

Quinn, M.

Rechnitzet, E.

Robertson D.

Robertson G. H.

Rossall, R. E.

Saint-Pierre, $H$.

Scallon, G.

Schwartz, D.

Scott, G.

Seheult, M. M. R.

Sheehan, B. S.

Sheffield, E. F.

Shore, B. M.

Sim, V. W.

Simard, P.

Skolnik, M.

Small, J.

Smith, H. F.

Sonnenfeld, $\mathrm{V}$.

Spitzer, W. O.

Stamp, R. M.

Storr, R. J.

Stuebing, B.

Sullivan, A. M.

Symons, T. H. B.

Thomas, A.

Thorhallson, J.

Toth, R. L.

Tracz, G. S.

Tremblay, G.

Troper, $\mathrm{H}$.

Tunner, A.

Turcotte, C.

Valence, $G$.

Wagner, R. M. K.

Watson, C.

Webster, B.

Wener, D.

Wideen, M. F.

Wighton, J. L.

Wigney, T. J.

Williamson, Wm. J.

Wilton, D. A.

Zaharia, G. N. S.

Zsigmond, Z. E.
E37

B34

A20

C33

B19, B20, B21, B22

A12, B12, E18

E40

B33

E40

F10

B23, C34

A23, C32, C35

E25

F11

C26

C36

$B 24, \mathrm{~B} 25$

A24, C37, C38

A10, A25, C13, C39

$\mathrm{C} 13$

C11

E1

A14

C40

B35

C16

A26

A27

A28

C41, E38

A29

E39

C15

B26

B27

E40

A30

E9

$\mathrm{C} 2$

B1

F12

B28

E41

B29

$\mathrm{C} 42$

$\mathrm{C} 43$

A30, E42

B30, B31, E43, E44

$\mathrm{C} 10$

B32

B33 
